ISSN 1392-3196 / e-ISSN 2335-8947

Zemdirbyste-Agriculture, vol. 107, No. 1 (2020), p. 33-40

DOI 10.13080/z-a.2020.107.005

\title{
Integrated weed management in long-term maize cultivation
}

\author{
Milena S. SIMIĆ ${ }^{1}$, Vesna DRAGIČEVIĆ ${ }^{1}$, Demosthenis CHACHALIS ${ }^{2}$, \\ Željko DOLIJANOVIĆ ${ }^{3}$, Milan BRANKOV ${ }^{1}$ \\ ${ }^{1}$ Maize Research Institute Zemun Polje \\ S. Bajića 1, 11080 Zemun-Belgrade, Serbia \\ E-mail: smilena@mrizp.rs \\ ${ }^{2}$ Benaki Phytopathological Institute \\ 8 Stefanou Delta, Kifissia, Athens 14561, Greece \\ ${ }^{3}$ University of Belgrade, Faculty of Agriculture \\ Nemanjina 6, 11080 Zemun, Serbia
}

\begin{abstract}
The effects of different measures within maize cropping technology, aimed to suppress weeds as a part of integrated weed management (IWM) system, are analysed and evaluated in this manuscript, in line with the results of longterm experiments. For sustainable maize (Zea mays L.) production, implementation of IWM system aiming to reduce reliance on chemical weed control within Europe is a key priority. This IWM system includes all possible solutions, such as preventive, direct, biological, mechanical and alternative measures. A cropping system approach is essential to manage weeds, utilize genetic potential of maize genotypes and reduce yield losses due to weed competition.

Long-term experiments are nowadays rare, but they are an excellent and reliable method for comparing cropping systems regarding yield and reduction of weed infestation level. In the research program implemented at the Maize Research Institute Zemun Polje in Central Serbia, the effects of different cropping measures and their interactions as a part of IWMs were studied during ten years. Maize rotations with winter wheat (Triticum aestivum L.) and soybean (Glycine max (L.) Merr.), combined with herbicide application, showed the best effect on weed biomass reduction, $92.1 \%$ and $92.2 \%$, respectively. Winter wheat was a better preceding crop for maize than soybean, especially in combination with herbicides applied in recommended as well as in half of recommended rate. Intensification of soil tillage significantly reduced maize weed infestation, especially abundance of perennial species: Johnson grass (Sorghum halepense (L.) Pers.), Canada thistle (Cirsium arvense (L.) Scop.) and field bindweed (Convolvulus arvensis L.). Other measures, such as type of fertilizer, maize row space and crop density, cover cropping and intercropping also affected weed biomass production in maize fields. Maize growing with reduced row spacing contributed to weed biomass reduction by $27.4 \%$, while application of slow-release urea contributed to crop competitiveness. Weed biomass in sweet maize (Zea mays L. convar. saccharata) grown with common vetch as a cover crop was significantly reduced $\left(48.5 \mathrm{~g} \mathrm{~m}^{-2}\right)$ compared with the treatment without a cover $\operatorname{crop}\left(564.3 \mathrm{~g} \mathrm{~m}^{-2}\right)$.
\end{abstract}

Key words: chemical control, integrated weed management, maize, system of measures, Zea mays.

\section{Introduction}

Maize (Zea mays L.) is a very important crop in Europe with a $28 \%$ of the total cereal production within European Union (EU) and an area of approximately 14 million hectares in 2016 (Eurostat, https://ec.europa. eu/eurostat/documents). Maize is cultivated for many different purposes, such as grain (for food, feed and processing), silage (green maize) and biogas feedstock. In cropping systems of central and southern Europe, grain maize production is dominant, whereas in northern Europe, it is typically grown for silage. Cropping systems are either continuous cropping or rotation with other crops (at various rotation sequences). Weed control is mostly herbicide-based; however, different integrated weed management (IWM) systems are implemented within Europe (Chachalis et al., 2018). Launching a more sustainable maize production with less dependence on herbicides (types and amounts), a cropping system approach is essential to manage weeds utilizing all possible IWM measures and solutions available (Bückmann et al., 2018). The week point is implementation of IWM, and some projects within EU are started to demonstrate that adoption of IWM will support cropping systems that are agronomically and environmentally more sustainable and more resilient without jeopardizing profitability or the steady supply of food, feed and biomaterials (Vasileiadis et al., 2015; Kudsk et al., 2018).

Please use the following format when citing the article:

Simić M. S., Dragičević V., Chachalis D., DolijanovićŽ., Brankov M. 2020. Integrated weed management in long-term maize cultivation. Zemdirbyste-Agriculture, 107 (1): 33-40. DOI 10.13080/z-a.2020.107.005 
Yield losses and weed competition need to be minimized in maize production to support global population rise and increased food demand (Popp, Csider, 2014). In maize, herbicides have always been the most preferred option for weed control; however, besides their contribution, negative effects have been also documented, including soil and ground water pollution, changed floristic composition of weed communities and occurrence of weed resistance (Peters, Strek, 2016). In recent surveys, more than $90 \%$ of herbicide resistance cases are associated with just few mode of action groups, predominantly acetyl-CoA carboxylase (ACCase) and acetolactate synthase (ALS) inhibitors (HRAC, www. hracglobal.com). In Serbia, suspected populations that have developed resistance to triazine and sulfonylurea herbicides were detected (Simić et al., 2013; Malidža et al., 2015). In maize, many changes in weed associations, such as prevalence of some invasive and troublesome species (e.g., Chenopodium sp., Amaranthus sp., Solanum nigrum, Datura stramonium, Ambrosia atremisiifolia, Sorghum halepense, Xathium strumarium and Abuthilon theophrasti) were documented as the consequence of continuous use of herbicides (Simić, Dolijanović, 2016).

The development and implementation of IWM strategies that provide good weed control, while reducing dependence on herbicides are still a challenge that has to be met (Harker, O'Donovan, 2013; Vasileiadis et al., 2015). The IWM system is based on the combined application of preventive, direct, mechanical, biological and alternative (non-chemical) measures and good knowledge of the field history aiming to give sustainable weed management solutions for specific cropping systems and certain maize growing areas (Swanton, Weise, 1991; Harker, O'Donovan, 2013). The core objective of such an IWM system is not to exclude the use of herbicides, but to achieve less reliance on chemical control (Owen, 2016). Ecologically based weed management strategies begin with the premise that no single tactic will remain successful in the face of genetically heterogeneous weed populations, range expansions by dispersing weed species, variable weather conditions and changes in crop management practices. Rather than relying on a single "large hammer", such as herbicide technology, to suppress weeds, ecologically based strategies seek to integrate many "little hammers" that act in concert to stress and kill a wide range of weed species at many points in their life cycles (Liebman, Gallandt, 1997).

The results of different measures applied within long-term experiments and aimed to suppress weeds as part of IWM system are analysed and evaluated in this manuscript. Long-term experiments are an excellent method for comparing cropping systems and crop rotation, soil tillage and fertilizer application as well as cover crops and intercrops are measures which can effectively manage weed infestation level with less reliance on chemical control while contributing to the protection of the agro-ecosystem.

\section{Materials and methods}

In the research program conducted in the Maize Research Institute Zemun Polje, Serbia in the vicinity of Belgrade, Central Serbia ( $44^{\circ} 52^{\prime}$ N $20^{\circ} 20^{\prime}$ E), the effects of different integrated weed management (IWM) measures in maize were studied during 2009-2016.

The trial with crop rotation was started in 2009 and it is still running. The main plots encompassed the following plant production systems: maize continuous cropping, maize-winter wheat rotation, maize-winter wheat-soybean and maize-soybean-winter wheat rotation. In all production systems, sub-plot treatments were represented by different weed control methods applied in maize: 1) application of the herbicide mixture of isoxaflutole and acetochlor (Merlin 750-WG + Trophy 768 -EC) at recommended rate $\left(105 \mathrm{~g} \mathrm{ha}^{-1}+1536 \mathrm{~g} \mathrm{ha}^{-1}\right.$ a.i.), after sowing and prior to maize emergence for control of broadleaf and grass weed seedlings; 2) 0.5 herbicide rate - application of the same herbicide mixture at half of the recommended rate $\left(52.5 \mathrm{~g} \mathrm{ha}^{-1}+768 \mathrm{~g} \mathrm{ha}^{-1}\right.$ a.i.); 3) weed free - hand hoeing treatment; 4) control treatment without herbicide application (weedy check). Each treatment had four replications in maize crop. The herbicides were applied with a hand-held sprayer calibrated to deliver $15 \mathrm{~L}$ at $300 \mathrm{kPa}$ (3 bars) with a flatfan $1.4 \mathrm{~mm}$ nozzle TeeJet E 04-80 (TeeJet Technologies, USA). In wheat and soybean, usual mixture of herbicides for broadleaf and grass weed control were applied.

The size of elementary plot was $28 \mathrm{~m}^{2}$. The number of weed species, number of individuals and weed biomass were recorded after uprooting weeds manually from randomly selected two places in the middle of the each plot with a $0.25 \mathrm{~m}^{2}$ quadrant, six to seven weeks after the application of herbicides.

The long-term experiment was set up 38 years ago to determine effectiveness of soil tillage systems: no-tillage, reduced and conventional tillage. The tillage systems encompassed three fertilizer treatments: 1) no fertilizers, 2) $330 \mathrm{~kg}$ of fertilizer per ha $\left(\mathrm{N} 150 \mathrm{~kg} \mathrm{ha}^{-1}\right.$, $\mathrm{P}_{2} \mathrm{O}_{5} 105 \mathrm{~kg} \mathrm{ha}^{-1}$ and $\mathrm{K}_{2} \mathrm{O} 75 \mathrm{~kg} \mathrm{ha}^{-1}$ ) and 3) $660 \mathrm{~kg}$ of fertilizer per ha (N $300 \mathrm{~kg} \mathrm{ha}^{-1}, \mathrm{P}_{2} \mathrm{O}_{5} 210 \mathrm{~kg} \mathrm{ha}^{-1}$ and $\mathrm{K}_{2} \mathrm{O}$ $150 \mathrm{~kg} \mathrm{ha}^{-1}$ ) with four replicates. The elementary plot size was $21 \mathrm{~m}^{2}$. In no-tillage treatment maize was planted by a four row planter John Deere 7200 (USA). The plant density of maize hybrid form FAO 600 maturity group was 64.935 plants $\mathrm{ha}^{-1}$. The broad-spectrum systemic herbicide glyphosate (2400 $\mathrm{g} \mathrm{ha}^{-1}$ a.i.) was applied as necessary to control weed vegetation, prior to planting in the no-tillage treatment. After planting and prior to maize emergence, the mixture of pre-emergence herbicides S-metolachlor + terbuthylazine at recommended rates (S-metolachlor $960 \mathrm{~g} \mathrm{ha}^{-1}+$ terbuthylazine $120 \mathrm{~g} \mathrm{ha}^{-1}$ a.i.), for grass and broadleaved weed control was applied in all treatments. The technics of herbicides application in this trial was according to the methods already performed in previous trials. Six weeks after herbicide application, number of weed species and their individuals as well as their biomass were evaluated.

The soil was slightly calcareous chernozem Haplic Chernozem (WRB, 2014) with 47\% clay and silt and $53 \%$ sand. The $0-30-\mathrm{cm}$ layer had $3.3 \%$ organic matter, $0.21 \%$ total nitrogen $(\mathrm{N}), 1.9 \%$ organic carbon (C), 14 and $31 \mathrm{mg}$ per $100 \mathrm{~g}$ of soil available phosphorus (P) and extractable potassium $(\mathrm{K})$, respectively, 9.7\% total calcium carbonate $\left(\mathrm{CaCO}_{3}\right)$ and $\mathrm{pH}$ 7.8.

Crop-weed interactions, i.e. competitive relations were studied in the experiments with combined application of modified spatial arrangement of maize, fertilizer form and herbicide rates. The maize hybrid ZPSC 388 (FAO 400) was sown manually on the $29^{\text {th }}$, $27^{\text {th }}$ and $18^{\text {th }}$ April in 2014, 2015 and 2016, respectively. This is a new generation hybrid developed by the experts of the Maize Research Institute Zemun Polje, Serbia. It is characterised by a high yielding potential and density tolerance of medium height, lower cob position and a vegetation period of 120-125 days. The experiment was laid out in a split-split plot block design with four replications. The standard urea (46\% $\mathrm{N}$ ) and slow-release urea (triamid UTEC (n-butyl) thiophosfate (NBPT) (Eurochem Agro, Germany) were both applied conventionally at the beginning of maize development. Within each $\mathrm{N}$ treatment as a main plot, the maize was grown with two row spacings (50 and $70 \mathrm{~cm}$ ) as sub-plots, which means that the sowing density was 59.500 and 83.333 plants ha ${ }^{-1}$, respectively. 
The sub-sub-plots were organized as treatments of the following herbicides: control (C) with no herbicides, pre-emergence application of herbicide mixture for grass and broadleaved weed control and post-emergence herbicides mix. The herbicides were applied with a handheld sprayer calibrated to deliver $15 \mathrm{~L}$ at $300 \mathrm{kPa}$ (3 bars) with a flat-fan $1.4 \mathrm{~mm}$ nozzle TeeJet E 04-80 (TeeJeet Technologies, USA). The application was performed at recommended rates of pre-emergence Dual Gold $960+$ Callisto $\left(960 \mathrm{~g} \mathrm{ha}^{-1}+120 \mathrm{~g} \mathrm{ha}^{-1}\right.$ a.i. $)$ and post-emergence Motivell + Callisto $\left(40 \mathrm{~g} \mathrm{ha}^{-1}+120 \mathrm{~g} \mathrm{ha}^{-1}\right.$ a.i. $)$. The elementary plot sizes were 20 and $28 \mathrm{~m}^{2}$ for the 50 - and $70-\mathrm{cm}$ row spacing, respectively.

The untreated control was also included. Three weeks after herbicide application, the dry biomass of uprooted weeds from $1 \mathrm{~m}^{2}$ was measured per each species and coefficient of efficacy was calculated.

Effects of crop rotation, soil tillage, fertilizer application as well as cover crops and intercrops as alternative measures, and their effects on weed distribution were studied in standard and maize hybrids with specific traits under rain-fed and irrigated conditions with and without herbicide application. Investigations with cover crops were conducted during the period 20112016, while experiments with herbicide application and efficacy were carried out continuously. The experiment with cover crops was established as a block design with four replications. As winter cover crops the following plants were grown: common vetch (Vicia sativa L.), winter oats (Avena sativa L.), fodder kale (Brassica oleracea (L.) convar. acephala) and two control treatments: a treatment in which the surface was covered with dead organic mulch and traditional uncovered soil surface. Before the sowing of cover crops (autumn) and sweet maize (spring) mineral fertilization was applied up to $120 \mathrm{~kg} \mathrm{ha}^{-1} \mathrm{~N}, 90 \mathrm{~kg} \mathrm{ha}^{-1} \mathrm{P}$ and $60 \mathrm{~kg} \mathrm{ha}^{-1} \mathrm{~K}$. Green biomass of the cover crops was incorporated into the soil, and sweet maize was sown without herbicide treatment. The number of weed species, the number of weed plants and their fresh and dry biomass were evaluated from uprooted weeds per $1 \mathrm{~m}^{2}$ six weeks after sweet maize sowing.

Zemun Polje is located in a semiarid region with good climate conditions for maize growing. The 14-year average air temperature and precipitation sum during maize growing season (April-September) was $20.0^{\circ} \mathrm{C}$ and $393.0 \mathrm{~mm}$ (data provided by the Institute Meteorological Station), and in some years the irrigation was required (Table 1). The average air temperature during the same period amounted to $20.6^{\circ} \mathrm{C}$.

The experimental data were statistically processed by analysis of variance (ANOVA) $F$ test, while differences between the means were tested by the least significant difference (LSD) test. Variations in the treatment means were considered significant at the $95 \%$ probability level.

Table 1. The average air temperature and precipitation sum in 2009-2016

\begin{tabular}{|c|c|c|c|c|c|c|c|c|}
\hline Year & $\begin{array}{l}\text { Temperature, } \\
\text { precipitation }\end{array}$ & April & May & June & July & August & September & $\begin{array}{l}\text { Average / } \\
\text { sum }\end{array}$ \\
\hline \multirow[b]{2}{*}{2009} & ${ }^{\circ} \mathrm{C}$ & 16.2 & 19.8 & 21.1 & 24.0 & 24.5 & 21.0 & 21.1 \\
\hline & $\mathrm{mm}$ & 6.0 & 64.0 & 153.0 & 79.0 & 45.0 & 4.0 & 351.0 \\
\hline \multirow[b]{2}{*}{2010} & ${ }^{\circ} \mathrm{C}$ & 13.5 & 18.0 & 21.3 & 24.3 & 24.1 & 17.8 & 19.8 \\
\hline & $\mathrm{mm}$ & 50.7 & 64.1 & 167.3 & 35.6 & 68.2 & 68.0 & 453.9 \\
\hline \multirow{2}{*}{2011} & ${ }^{\circ} \mathrm{C}$ & 14.6 & 17.3 & 22.4 & 24.2 & 24.8 & 21.6 & 20.8 \\
\hline & $\mathrm{mm}$ & 14.9 & 89.6 & 25.9 & 66.9 & 67.9 & 36.4 & 301.6 \\
\hline \multirow{2}{*}{2012} & ${ }^{\circ} \mathrm{C}$ & 14.4 & 17.9 & 24.6 & 27.1 & 26.2 & 22.1 & 22.1 \\
\hline & $\mathrm{mm}$ & 56.2 & 58.5 & 14.8 & 19.8 & 4.8 & 20.7 & 174.8 \\
\hline \multirow{2}{*}{2013} & ${ }^{\circ} \mathrm{C}$ & 14.9 & 19.7 & 21.9 & 23.8 & 23.7 & 16.9 & 20.2 \\
\hline & $\mathrm{mm}$ & 14.9 & 93.9 & 37.8 & 16.0 & 12.7 & 70.1 & 245.4 \\
\hline \multirow{2}{*}{2014} & ${ }^{\circ} \mathrm{C}$ & 13.7 & 17.4 & 21.1 & 23.2 & 22.6 & 18.0 & 19.3 \\
\hline & $\mathrm{mm}$ & 84.8 & 192.5 & 71.2 & 187.4 & 41.0 & 75.6 & 625.5 \\
\hline \multirow{2}{*}{2015} & ${ }^{\circ} \mathrm{C}$ & 12.9 & 19.1 & 22.1 & 26.4 & 25.7 & 20.2 & 21.1 \\
\hline & $\mathrm{mm}$ & 19.7 & 97.8 & 31.1 & 7.2 & 56.0 & 73.6 & 285.4 \\
\hline \multirow{2}{*}{2016} & ${ }^{\circ} \mathrm{C}$ & 15.3 & 17.6 & 23.0 & 24.2 & 22.3 & 19.4 & 20.3 \\
\hline & $\mathrm{mm}$ & 51.9 & 47.4 & 107.4 & 33.6 & 43.2 & 36.6 & 320.1 \\
\hline Average & ${ }^{\circ} \mathrm{C}$ & 13.7 & 18.1 & 22.0 & 24.1 & 23.4 & 18.9 & 20.0 \\
\hline $1990-2016$ & $\mathrm{~mm}$ & 52.1 & 96.1 & 80.1 & 72.1 & 48.7 & 58.4 & 393.0 \\
\hline
\end{tabular}

\section{Results and discussion}

The obtained results pointed out the advantages of the investigated measures in efficient weed control in maize crop. Combined and continuous application of them within the system of integrated measures is productive and environmentally acceptable in the longterm period.

Crop rotation, as a measure that disrupts the life cycle of weeds and disallows them to adapt, is very important within an integrated weed management (IWM) system (Swanton, Weise, 1991). It means proper arrangement of crops in time and space in order to better use soil potential and climate (Kovačević et al., 2008). Rotation of row and dense crops, legume and cereal crops that include rotation of growing technologies and herbicides with different mode of action prevent wide spreading and domination of troublesome and invasive weed species. Cultivation of different genotypes influences the composition and structure of field weed community, the number of individuals as well as the bank of weed seeds in the soil, disrupts the life cycle of weeds and prevents the spread and dominance of any species
(Simić et al., 2016). Generally, the most adopted system in Serbia is the two crop (maize and winter wheat) rotation, even though the recommendations are to include legume crops as part of a three crop rotation (Videnović et al., 2013). Rotation of crops also includes rotation of herbicides and their modes of action, allowing a possible reduction in pesticide use (Anderson, 2006). Rotation of herbicide mode of action is very important because of the latest EU regulations for pesticide production and use (http://www.epa.gov/pesticides/regulating/restricted. $\mathrm{htm})$. According to the previous survey, the use of crop rotation, even two-crop rotation, such as maize and winter wheat, significantly reduces weed biomass compared to the maize growing in a monoculture (Spasojević et al., 2012).

Results of long-term experiment showed that in the first year of the crop rotation, the total fresh weight of weeds depended on the applied amount of herbicides and was almost the same in continuous maize and in the maize $\rightarrow$ winter wheat rotation. More than that, the positive effects were very obvious after two rotation cycles - fresh weight of weeds was rapidly lower $(85.4 \mathrm{~g}$ $\mathrm{m}^{-2}$ at the rotated field, maize and winter wheat) than in maize continuous cropping $\left(573.1 \mathrm{~g} \mathrm{~m}^{-2}\right)$ (Table 2$)$. 
Table 2. Total weed biomass $\left(\mathrm{g} \mathrm{m}^{-2}\right)$ according to the cropping systems and herbicide application

\begin{tabular}{|c|c|c|c|c|c|c|c|c|c|}
\hline $\begin{array}{l}\text { Cropping } \\
\text { system }\end{array}$ & $\begin{array}{l}\text { Herbicide } \\
\text { application }\end{array}$ & 2009 & 2010 & 2011 & 2012 & 2013 & 2014 & \multicolumn{2}{|c|}{ Average } \\
\hline Maize & Control & 4163.2 & 1987.6 & 2077.0 & 2645.8 & 5653.7 & 1293.1 & 2970.1 & $100 \%$ \\
\hline continuous & $0.5 \mathrm{RR}$ & 681.9 & 1190.4 & 648.8 & 955.6 & 872.5 & 310.3 & 776.6 & $-73.8 \%$ \\
\hline cropping & $\mathrm{RR}$ & 440.1 & 630.4 & 417.9 & 541.7 & 573.1 & 194.0 & 466.2 & $-84.3 \%$ \\
\hline Maize & Control & 3392.0 & & 2114.4 & & 4016.1 & & 3174.2 & $100 \%$ \\
\hline and & $0.5 \mathrm{RR}$ & 812.1 & & 290.7 & & 160.3 & & 421.0 & $-86.7 \%$ \\
\hline winter wheat & RR & 535.3 & & 120.7 & & 85.4 & & 247.1 & $-92.2 \%$ \\
\hline Maize, soybean & Control & 5861.6 & & & 3628.5 & & & 4745.1 & $100 \%$ \\
\hline and & $0.5 \mathrm{RR}$ & 1454.7 & & & 564.3 & & & 1095.5 & $-76.9 \%$ \\
\hline winter wheat & RR & 555.6 & & & 189.4 & & & 372.5 & $-92.1 \%$ \\
\hline
\end{tabular}

$\mathrm{RR}$ - recommended rate

The application of herbicides in the amount of half of the recommended rate in the field rotation $(421.0$ $\mathrm{g} \mathrm{m}^{-2}$ ) decreased total fresh weight of weeds by $46 \%$ in comparison to the monoculture field $\left(776.6 \mathrm{~g} \mathrm{~m}^{-2}\right)$. The six year average of the three-crop rotation (maize $\rightarrow$ soybean $\rightarrow$ winter wheat) and two-crop rotation (maize $\rightarrow$ winter wheat), together with the recommended rate of herbicides showed the best effect on weed biomass reduction, $92.1 \%$ and $92.2 \%$, respectively (Table 2 ). Results showed that winter wheat was a better preceding crop for maize than soybean, especially in combination with herbicide application (either at recommended rate or half the recommended rate). Although use of half the recommended rate of herbicides is not considered a key point in an IWM system because of weed resistance, our results of long-term experiments showed a clear advantage of this approach. On the other hand, weed suppression is probably caused by mixture of herbicides with different mode of action, as clearly is recommended by an IWM system. In such long-term experiments, use of crop rotation could significantly affect the level of emergence of weeds in the crop and weed seed bank richness; the highest number of weed seeds was identified in maize monoculture (6425.0 seeds $\left.\mathrm{m}^{-2}\right)$ as compared to the maize and winter wheat $\left(2962.5\right.$ seeds $\left.\mathrm{m}^{-2}\right)$ and maize, winter wheat and soybean rotation (2375.0 seeds $\mathrm{m}^{-2}$ ) (Simic et al., 2014).

Soil tillage. Proper soil tillage usually increases soil potential and productivity of the maize cropping system. Considering biological and ecological relationships and environmental conservation, it is necessary to apply effective tillage practices (Woźniak, Kawecka-Radomska, 2016). This basic measure manages crop residues, provides efficient water use and erosion protection and, regarding weed control, influences positively crop competitiveness and provides better efficacy of the applied herbicides. For perennial weed species control, application of conventional tillage is especially efficient (Simić et al., 2012). The conventional or traditional soil tillage applied in maize production in Serbia requires a greater number of different methods of primary tillage and pre-sowing soil preparation reduces biomass of rhizomes of perennial weeds and contributes to the achievement of the highest grain yields (Videnović et al., 2011). Nowadays, systems of reduced tillage, particularly direct sowing, are widely used in North America, Australia and South America and, in the last ten years, in Europe and some developing countries (Dumanski, 2010; Llewellyn et al., 2012). However, the use of the reduced soil cultivation requires the implementation of chemical measures for proper weed control.

Under the agro-ecological conditions of Zemun Polje, when reduced tillage or no-tillage is applied, greater amounts of herbicides are necessary for the suppression of weeds, particularly perennials. The highest number of weeds per $\mathrm{m}^{2}$ was recorded in the treatments with direct sowing (no-tillage) and reduced tillage, which is in accordance with the significant distribution of perennial weed species that have very developed root systems and pronounced vegetative propagation. From a longterm experiment, one year overview showed that soil tillage and level of fertilizer application influenced weed fresh biomass and, because of high propagation level of perennial species, weed fresh biomass was the highest under no-tillage (149.6 $\mathrm{g} \mathrm{m}^{-2}$ ) even without fertilizers application (Fig.).

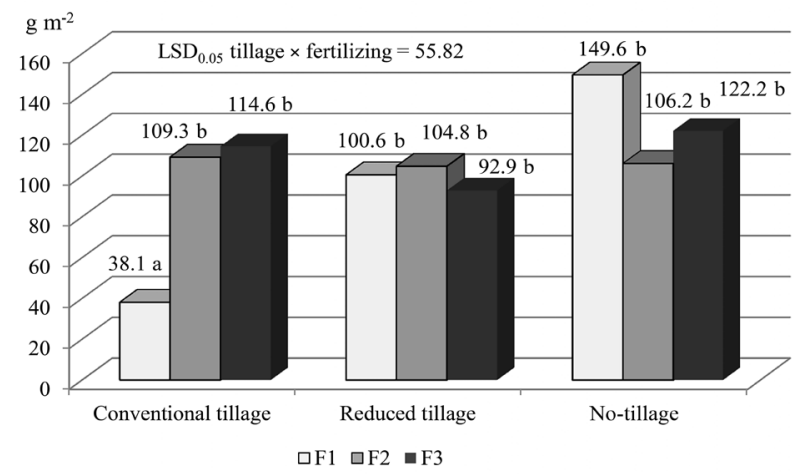

F1 - $0 \mathrm{~kg}$; F2 - $150 \mathrm{~kg} \mathrm{ha}^{-1} \mathrm{~N}, 105 \mathrm{~kg} \mathrm{ha}^{-1} \mathrm{P}$ and $75 \mathrm{~kg} \mathrm{ha}^{-1} \mathrm{~K}$; F3 - $330 \mathrm{~kg} \mathrm{ha}^{-1} \mathrm{~N}, 211 \mathrm{~kg} \mathrm{ha}^{-1} \mathrm{P}$ and $150 \mathrm{~kg} \mathrm{ha}^{-1} \mathrm{~K}$

Figure. Weed fresh biomas $\left(\mathrm{g} \mathrm{m}^{-2}\right)$ in maize crop as influenced by different soil tillage systems and level of fertilizers in 2017

Results of regression analysis pointed out that weed fresh biomass decreased when intensity of soil tillage increased from no-tillage to conventional tillage (Auškalnienè et al., 2018). On the other hand, weed fresh biomass was negatively correlated $(R=-0.66)$ with maize yield in unfavourable and dry years (Simić, Dolijanović, 2016). Data from the long-term experiments showed that soil tillage significantly influenced weed presence and grain yield, and the best results were achieved with conventional tillage (Videnović et al., 2011). The number of weeds per $\mathrm{m}^{2}$ was the highest under reduced tillage ( 91.3 and 74.0 weeds per $\mathrm{m}^{2}$ ) and the lowest in conventional tillage (20.2 and 1.8 weeds per $\mathrm{m}^{2}$ ), respectively, for 2010 and 2011 growing seasons (Simić et al., 2012).

Herbicide efficacy. The commonly used herbicides for grass and broadleaf weed control in maize include pre-emergence and post-emergence herbicide mixtures. Nowadays, the use of post-emergence herbicides has increased; herbicides from sulfonylurea and triketone groups are the most commonly used post-emergence herbicides in maize. Applied as postemergence treatment, mesotrione at $35 \mathrm{~g} \mathrm{ha}^{-1}$ and higher controlled common lambsquarters (Chenopodium album L.) $91 \%$ or greater, while applied at $140 \mathrm{~g} \mathrm{ha}^{-1}$ controlled smooth pigweed (Amaranthus hybridus L.) greater than 
97\%. Common ragweed (Ambrosia artemisiifolia L.) control by post-mesotrione was inconsistent, ranging from $56 \%$ to $97 \%$. The ranking among weed species based on their sensitivity to mesotrione was: Abutilon theophrast $i=$ Chenopodium album $=$ Solanum nigrum $=$ Xathium strumarium $>$ Amaranthus retroflexus $=$ Polygonum persicaria $>$ Echinochloa crus-galli > Portulaca oleracea (Armel et al., 2003). According to the results of Zhang et al. (2013), nicosulfuron and its mixture with mesotrione effectively controlled broadleaved and grass weeds even when their rates were reduced by $67 \%$ and $33 \%$, respectively. Data from the long-term experiment, carried out on chernozem type of soil in Zemun Polje, with application of post-emergence herbicide mixture of mesotrione + nicosulfuron, showed very good weed control in all three seasons (2014$2016)$. The best efficacy $(96.65 \%)$ was observed in postemergence treatment with mesotrione + nicosulfuron in a reduced row distance system $(50 \mathrm{~cm}$ inter-row distance) and standard urea application (Simić et al., 2017).

In maize, nitrogen level in the soil is also a determining factor for the herbicide efficacy. Studies conducted in controlled conditions showed that some weed species grown under low soil $\mathrm{N}$ conditions may escape control by herbicides (Cathcart et al., 2004). Pre-emergence mixture of S-metolachlor + mesotrione provided good control and at the higher extent when it was applied after slow-release urea (Table 3).

Table 3. Coefficient of efficacy of herbicides as influenced by application time and type of fertilizer in maize

\begin{tabular}{|c|c|c|c|c|c|c|}
\hline \multirow[b]{2}{*}{ Year } & \multirow{2}{*}{\multicolumn{2}{|c|}{$\begin{array}{c}\text { Pre-emergence treatment } \\
\text { standard } \\
\text { urea } \\
\end{array}$}} & \multirow{2}{*}{\multicolumn{2}{|c|}{$\begin{array}{c}\text { Post-emergence treatment } \\
\text { slow-release } \\
\text { urea } \\
\end{array}$}} & \multicolumn{2}{|c|}{ Average } \\
\hline & & & & & \multirow{2}{*}{$\begin{array}{c}\begin{array}{c}\text { pre-emergence } \\
\text { treatment }\end{array} \\
95.8\end{array}$} & \multirow{2}{*}{$\begin{array}{c}\begin{array}{c}\text { post-emergence } \\
\text { treatment }\end{array} \\
89.8\end{array}$} \\
\hline 2014 & $96.5 \mathrm{a}$ & $95.2 \mathrm{a}$ & $87.6 \mathrm{c}$ & $91.9 \mathrm{~b}$ & & \\
\hline 2015 & $91.0 \mathrm{~b}$ & $90.0 \mathrm{~b}$ & $98.8 \mathrm{a}$ & $98.9 \mathrm{a}$ & 90.5 & 98.9 \\
\hline \multirow[t]{2}{*}{ Average } & $93.7 \mathrm{a}$ & $92.6 \mathrm{a}$ & $93.2 \mathrm{~b}$ & $95.4 \mathrm{a}$ & 93.2 & 94.3 \\
\hline & \multicolumn{2}{|c|}{$\mathrm{LSD}_{0.05}=3.66$} & \multicolumn{2}{|c|}{$\mathrm{LSD}_{0.05}=4.89$} & & \\
\hline
\end{tabular}

Note. The values with the same letters are not significantly different at 0.05 level.

The best efficacy, in average, was observed in post-emergence treatment in 2015, after application of the both forms of urea $(98.78 \%$ and $98.94 \%)$. Use of preemergence herbicides showed a high efficacy in many favourable seasons. In double crop rotation (maize $\rightarrow$ winter wheat) and in three crop rotation (maize $\rightarrow$ winter wheat $\rightarrow$ soybean), the number of weed species (both, broadleaves and grass weeds) was lower, especially when recommended rate of pre-emergence herbicides was applied. Differences between abundance of annual and perennial weeds are related, and biomass of annual weed species decreased after one cycle of rotation, while biomass of perennials increased in the treatments and control as well (Simić et al., 2016). In other studies, $\mathrm{S}$-metolachlor gave the best results as a pre-emergence treatment for grass weed control (Pannacci et al., 2007). And, in average for two years, in average for two row spacings and urea forms, efficacy of pre-emergence herbicides was $93.2 \%$ and of post-emergence treatment $-94.3 \%$ (Table 3 ).

Increased crop competitiveness. Measures that give a clear advantage of the crop to compete with weeds are also a component of an IWM system. Such solutions usually include growing of competitive genotypes, application of higher crop densities, smaller inter-row distances and various space arrangements of crops (Travlos et al., 2011; Swanton et al., 2015). The plant competitive ability can be expressed in the following two categories: the crop-weed suppressive ability that results in the reduction of weed biomass, and the crop-weed tolerance - ability of crops to tolerate weed effects having at the same time high yields (Williams et al., 2008). Weed competition affects physiological processes in maize plants and modifies their morphology. It affects their light use efficiency and physiological processes relevant for productivity, such as chlorophyll and carotenoid contents (Spasojević et al., 2014). Plant canopies can be structurally characterized by their harvest and leaf area index. Those two indices illustrate the intensity of stress and pressure present in crop stand, caused by presence of weeds and their biomass.

Three year experiment on chernozem type of soil in Central Serbia showed that the effect of row spacing was noticeable but not significant due to weed biomass variation between 50 and $70 \mathrm{~cm}$ of row spacing ( 81.5 and $112.3 \mathrm{~g} \mathrm{~m}^{-2}$ ), but row spacing interaction with herbicide treatment showed significant effect in weed biomass reduction (Table 4 ).

Results showed that weed biomass was lower especially in the treated plot - in a system with a $50-\mathrm{cm}$ row spacing $\left(81.5 \mathrm{~g} \mathrm{~m}^{-2}\right)$ compared to the conventional $70-\mathrm{cm}$ row spacing $\left(112.3 \mathrm{~g} \mathrm{~m}^{-2}\right)$. Maize cultivation with reduced row spacing contributed to weed biomass reduction by $27.4 \%$, while the application of slow-

Table 4. Weed aboveground biomass $\left(\mathrm{g} \mathrm{m}^{-2}\right)$ after application of post-emergence herbicides

\begin{tabular}{|c|c|c|c|c|c|c|c|c|c|c|}
\hline \multirow[b]{2}{*}{ Year } & & \multicolumn{2}{|c|}{ Standard urea } & \multicolumn{2}{|c|}{ Slow-release urea } & \multicolumn{2}{|c|}{ Average } & \multicolumn{2}{|c|}{ Average } & \multirow[b]{2}{*}{ Average } \\
\hline & & $50 \mathrm{~cm}$ & $70 \mathrm{~cm}$ & $50 \mathrm{~cm}$ & $70 \mathrm{~cm}$ & $50 \mathrm{~cm}$ & $70 \mathrm{~cm}$ & $\begin{array}{l}\text { standard } \\
\text { urea }\end{array}$ & $\begin{array}{c}\text { slow-release } \\
\text { urea }\end{array}$ & \\
\hline \multirow[b]{2}{*}{2014} & $\mathrm{~T}$ & 88.1 & 253.7 & 163.6 & 141.5 & 125.8 & 197.6 & 170.9 & 152.5 & 161.7 \\
\hline & $\mathrm{C}$ & 1353.9 & 1969.1 & 1163.8 & 1915.9 & 1258.8 & 1942.5 & 1661.5 & 1539.8 & 1600.6 \\
\hline \multirow{2}{*}{2015} & $\mathrm{~T}$ & 26.9 & 50.5 & 80.6 & 53.3 & 53.7 & 51.9 & 38.7 & 66.9 & 52.8 \\
\hline & $\mathrm{C}$ & 4710.4 & 4126.7 & 4685.1 & 4957.1 & 4697.7 & 4541.9 & 4418.5 & 4821.1 & 4619.8 \\
\hline \multirow{2}{*}{2016} & $\mathrm{~T}$ & 54.6 & 127.2 & 75.7 & 47.9 & 65.1 & 87.5 & 91.1 & 61.8 & 76.4 \\
\hline & $\mathrm{C}$ & 1889.6 & 1860.9 & 1666.4 & 1449.0 & 1778.0 & 1654.9 & 1875.2 & 1557.7 & 1716.4 \\
\hline \multirow{4}{*}{ Average } & $\mathrm{T}$ & 56.5 & 143.8 & 106.6 & 80.9 & $81.5 \mathrm{~b}$ & $112.3 \mathrm{~b}$ & $100.2 \mathrm{~b}$ & $93.7 \mathrm{~b}$ & 96.9 \\
\hline & $\mathrm{C}$ & 2651.3 & 2652.2 & 2505.1 & 2774.0 & $2578.2 \mathrm{a}$ & $2713.1 \mathrm{a}$ & $2651.7 \mathrm{a}$ & $2639.5 \mathrm{a}$ & $2645.6 * *$ \\
\hline & & & & & & \multicolumn{2}{|c|}{$\mathrm{LSD}_{0.05}=1687.0$} & \multicolumn{2}{|c|}{$\mathrm{LSD}_{0.05}=1688.0$} & \multirow{2}{*}{$\mathrm{LSD}_{0.05}=1091.0$} \\
\hline & & & & & & 1329.8 & 1412.7 & 1375.9 & 1366.6 & \\
\hline
\end{tabular}

Note. $\mathrm{T}$ - post-emergence herbicide treatment, $\mathrm{C}$ - control; the values with the same letters are not significantly different at 0.05 level; ** - significant at 0.01 . 
release urea contributed to crop competitiveness, in average for three years. On average, after the application of post-emergence herbicides, total biomass of weeds was significantly lower in the treated plot $\left(96.9 \mathrm{~g} \mathrm{~m}^{-2}\right)$ than in untreated control $\left(2645.6 \mathrm{~g} \mathrm{~m}^{-2}\right)$, which shows that crop-weed interactions were highly dependent on herbicide applications.

Sweet maize hybrids as well as standard hybrids respond differently to growing in high densities, depending on the genotype and the duration of the growing period (Hao, 1999). The later the FAO maturity group is, the greater is the total above ground biomass of hybrids (Garcia y Garcia et al., 2009). It has been reported that in sweet maize hybrids, the increased crop density reduced the number of weed species and fresh weight of weeds (Williams et al., 2008).

Intercropping and cover cropping. Some ecological measures, such as cover crops, intercropping, mulching and mechanical control, are also an important part of IWM system. Plant species that could be utilized as cover crops, also contribute to the biodiversity of agro-ecosystems (Albrecht et al., 2015). The first step in selecting a cover crop species is to determine the main goal of the cover crop. Many organic producers select cover crops to enrich soil with nitrogen, control weeds, protect soil and/or increase soil organic matter. Cover cropping could be an effective measure for weed control, especially when the crop is produced for direct human consumption, such as sweet corn and popcorn maize (Dolijanović, Simić, 2015). Such approaches could be combined successfully with tillage systems, and they could even replace chemical and mechanical weed control (Weber, Gerhards, 2015).

The efficacy of mowed or desiccated mulch to manage weeds seems to depend mostly on soil cover and light interception effects, rather than on the effects of altered moisture or temperature regimes, allelopathy or mechanical impedance (Liebman, Davis, 2000). Some cover crops suppress weeds during growth and after termination (Blackshaw et al., 2001). In addition to competition-based or physical weed suppression, certain cover crops are known to suppress weeds through allelopathy as well (Singh et al., 2003). In allelopathy, certain biochemical cover crop compounds are degraded and those compounds are phytotoxic or inhibit seed germination. Some well-known examples of allelopathic cover crops are rye (Secale cereale L.), hairy vetch (Vicia villosa Roth.), red clover (Trifolium pratense L.) and species from the Brassicaceae family, particularly mustards (Haramoto, Gallandt, 2004).

In long-term experiments, ground cover greater than $50 \%$ resulted in an exponential increase of the weed suppression. Winter cover crops were best adapted to areas, where the crop had enough time to be established in the fall and without any soil moisture deficits in the spring (Dolijanović et al., 2013). More precisely between the five tested cover crops, common vetch showed the best efficacy in reduction of number of weed species, number of weed individuals as well as fresh biomass and dry matter of weeds in sweet maize (Table 5).

Table 5. Influence of cover crops on weed abundance in sweet maize (2012-2013)

\begin{tabular}{|c|c|c|c|c|c|}
\hline & \multicolumn{4}{|c|}{ Cover crop } & \multirow[b]{2}{*}{$\begin{array}{c}\text { Without a cover } \\
\text { crop }\end{array}$} \\
\hline & $\begin{array}{l}\text { common vetch } \\
\text { (Vicia sativa L.) }\end{array}$ & $\begin{array}{c}\text { winter oats } \\
\text { (Avena sativa L.) }\end{array}$ & $\begin{array}{c}\text { fodder kale } \\
(\text { Brasica oleracea } \mathrm{L} . \\
\text { covar. acephala })\end{array}$ & $\begin{array}{l}\text { organic } \\
\text { mulch }\end{array}$ & \\
\hline Number of weed species & $7 \mathrm{a}$ & $13 \mathrm{c}$ & $8 \mathrm{a}$ & $8 \mathrm{a}$ & $10 \mathrm{~b}$ \\
\hline Number of weed individuals & $13.1 \mathrm{a}$ & $22.3 \mathrm{~b}$ & $21.6 \mathrm{~b}$ & $14.6 \mathrm{a}$ & $20.8 \mathrm{~b}$ \\
\hline Weed biomass $\mathrm{g} \mathrm{m}^{-2}$ & $48.5 \mathrm{a}$ & $285.4 \mathrm{~b}$ & $286.4 \mathrm{~b}$ & $394.4 \mathrm{~b}$ & $564.3 \mathrm{c}$ \\
\hline Weed dry matter $\mathrm{g} \mathrm{m}^{-2}$ & $13.5 \mathrm{a}$ & $58.7 \mathrm{a}$ & $47.2 \mathrm{~b}$ & $92.9 \mathrm{c}$ & $137.5 \mathrm{~d}$ \\
\hline
\end{tabular}

Note. The values with the same letters are not significantly different at 0.05 level.

The obtained results also showed that the number of weed species was markedly lower in the treatment with common vetch cover $(7$ species $)$ in comparison to winter oats treatment (13 species), while their biomass (48.5 and $13.5 \mathrm{~g} \mathrm{~m}^{-2}$ ) was significantly reduced in comparison to the treatment without a cover crop (564.3 and $137.5 \mathrm{~g} \mathrm{~m}^{-2}$ ). In addition, cover crops encompassing winter oats increased fresh weight of sweet maize (Janosevic et al., 2017). Growing maize intercropped with soybean resulted in higher weed control efficacy; the best effects were observed with alternate rows model and without application of fertilizers (Dolijanović et al., 2015).

\section{Conclusions}

1. A successful application of integrated weed management (IWM) system in maize requires full exploitation of research knowledge acquired from the long-term experiments.

2 . The use of crop rotation, even two-crop rotation, such as maize and winter wheat, together with herbicide application at recommended as well as at half of recommended rate, contributed to the reduction of weed biomass compared to the maize grown in a monoculture. In long-term experiments, six years' results showed that maize $\rightarrow$ soybean $\rightarrow$ winter wheat and maize $\rightarrow$ winter wheat together with recommended rate of herbicides had the best effect on weed biomass reduction, 92.1\% and $92.2 \%$, respectively.
3. The conventional tillage is considered the most effective non-chemical weed control method. In the long-term experiments, when reduced tillage or no-tillage was applied, greater amounts of herbicides were needed for weed control, particularly when perennials prevailed.

4. In the long-term experiments, reduced herbicide rates could be successfully applied when the crop is more competitive than weeds (e.g., denser crops due to a reduced row distance of $50 \mathrm{~cm}$ ). In the long-term experiments, ground cover greater than 50\% resulted in an exponential increase of weed suppression. Winter cover crops are a good solution for weed suppression, when there is enough time until spring and no soil moisture deficit is expected in the spring. Additionally, the common vetch proved to be the best solution for weed management in maize.

5. Although the task of implementing IWM in agro-ecosystems is a key priority, there is a lack of use of such system in most crops including maize. Research so far has identified numerous single IWM tactics with limited integration into system level to tackle the weed infestation problems.

6. Results of long-term experiments would offer validated temporal and spatial weed control solutions. As such, future research should focus on IWM system that offers innovative weed control solutions, also on monitoring and evaluations of the measures and their impact on the cropping systems and the environment. 


\section{Acknowledgments}

This paper is the result of the research project "Integrated system of field crops cultivation: conservation of biodiversity and soil fertility" (TR 31037), supported by the Ministry of Education, Science and Technological Development of the Republic of Serbia.

Received 04022019

Accepted 19112019

\section{References}

1. Albrecht H., Lang M., Truffel C., Prestele J., Wiesinger K. Kollmann J. 2015. Impact of cover crops and crop rotations on the re-establishment on threatened arable plants. Proceedings of $17^{\text {th }}$ European Weed Research Society Symposium. Montpellier, France, p. 184.

2. Anderson R. L. 2006. A rotation design that aids annual weed management in a semiarid region. Singh H. P. et al. (eds). Handbook of sustainable weed management. New York, London, p. 159-177.

3. Armel G., Henry R., Wilson P., Richardson J. R., Hines E. T. 2003. Mesotrione combinations in no-till corn (Zea mays). Weed Technology, 17: 111-116. https://doi.org/10.1614/0890037X(2003)017[0111:MCINTC]2.0.CO;2

4. Auškalnienė O., Kadžienè G., Janušauskaitė D., Supronienė S. 2018. Changes in weed seed bank and flora as affected by soil tillage systems. Zemdirbyste-Agriculture, 105 (3): 221-226. https://doi.org/10.13080/z-a.2018.105.028

5. Blackshaw R. E., Moyer J. R., Doram R. C., Boswell A. L. 2001. Yellow sweet clover, green manure, and its residues effectively suppress weeds during fallow. Weed Science, 49: 406-413. https://doi.org/10.1614/00431745(2001)049[0406:YSGMAI]2.0.CO;2

6. Bückmann H., Mission Bojer O., Montull H. M., Manfred R., Ryhdahl P., Taberner A., Verschwell A. 2018. Integrated weed control with DSS-IWM, an improved European Decision Support System. Proceedings of the $18^{\text {th }}$ European Weed Research Society Symposium. Ljubljana, Slovenia, p. 215

7. Cathcart R. J., Chandler K., Swanton C. 2004. Fertilizer nitrogen rate and the response of weeds to herbicides. Weed Science, 52: 291-296.

https://doi.org/10.1614/WS-03-049R

8. Chachalis D., Bogdan I., Gertis A., Gitsopoulos T., Leskovšek R., Mennan H., Stoyanov Neshev N., Sallaku F., Scepanovic M., Simic M., Simoncic A., Travlos I., Vasilikiotis C., Vizantinopoulos S., Yanev M., Kudsk P. 2018. Eliminate obstacles for development, implementation and adoption of Integrated Weed Management (IWM) into cropping systems in South East Europe. Proceedings of the $18^{\text {th }}$ European Weed Research Society Symposium. Ljubljana, Slovenia, p. 216.

9. Dolijanović Ž., Simić M. 2015. Intercropping systems: principles, production practices and agronomic benefits. Gorawala P., Mandhatri S. (eds). Agricultural research updates, vol. 12. New York, USA, p. 1-43. https://doi.org/10.5644/Herb.15.1.01

10. Dolijanović Ż., Momirović N., Simić M., Kovačević D., Oljača S., Mikić A. 2013. Fall and spring sown legumecereal cover crops for sweet maize production. Proceedings of $2^{\text {nd }}$ international scientific conference Soil and Crop Management: Adaptation and Mitigation of Climate Change. Osijek, Croatia, p. 128-135.

11. Dolijanović Ž., Oljača S., Kovačević D., Simić M., Dragičević V., Popović V. 2015. Weediness of a maize and soybean intercropping system. Herbologia (Sarajevo, Bosnia and Herzegovina), 15 (1): 1-10. https://doi.org/10.5644/Herb.15.1.01

12. Dumanski J. 2010. Criteria for adoption of conservation agriculture and zero tillage in developing countries. Lindwall C., Sonntag B. (eds). Landscapes transformed: the history of conservation tillage and direct seeding. The University of Saskatchewan's Knowledge Impact in Society. Saskatoon, Canada, chapter 16, p. 189-198.

13. Garcia y Garcia A., Guera L. C., Hoogenboom G. 2009. Impact of planting date and hybrid on early growth of sweet corn. Agronomy Journal, 101: 193-200. https://doi.org/10.2134/agronj2007.0393
14. Hao X. 1999. Effects of plant density on growth, yield, and quality of fresh market sweet corn. Horticultural Science, 34: 478-480. https://doi.org/10.21273/HORTSCI.34.3.478E

15. Haramoto E. R., Gallandt E. R. 2004. Brassica cover cropping for weed management: a review. Renewable Agriculture and Food Systems, 19: 187-198. https://doi.org/10.1079/RAFS200490

16. Harker K. N., O’Donovan J. T. 2013. Recent weed control, weed management and integrated weed management. Weed Technology, 27: 1-11. https://doi.org/10.1614/WT-D-12-00109.1

17. Janosevic B., Dolijanovic Z., Dragicevic V., Simic M., Dodevska M., Djordjevic S., Moravcevic D. J., Miodragovic R. 2017. Cover crop effects on the fate of $\mathrm{N}$ in sweet maize (Zea mays L. saccharata Sturt.) production in a semiarid region. International Journal of Plant Production, 11 (2): 285-294. http://ijpp.gau.ac.ir/ article_3425 732d7d53652c01d1a0cb572089d042ab.pdf

18. Kovačević D., Dolijanović Ž., Oljača S., Jovanović Ž. 2008. The influence of crop rotation in weed control. Acta Herbologica, 17: 45-51 (in Serbian).

19. Kudsk P., Sonderskov M., Bonin L., GonzalezAndujar H. L., Jensen J. E., Melander B., Moonen C., Riemens M., Sattin M., Schaffner U., Storkey J. 2018. IWMPRAISE - an EU HORIZON 2020 project on integrated weed management. Proceedings of the $18^{\text {th }}$ European Weed Research Society Symposium. Ljubljana, Slovenia, p. 222.

20. Liebman M., Gallandt E. R. 1997. Many little hammers: ecological management of crop-weed interactions. Jackson L. E., Orlando F. (eds). Ecology in agriculture. Academic Press, p. 287-339. https://doi.org/10.1016/B978-012378260-1/50010-5

21. Liebman M., Davis A. S. 2000. Integration of soil, crop, and weed management in low-external-input farming systems. Weed Research, 40: 27-47. https://doi.org/10.1046/j.1365-3180.2000.00164.X

22. Llewellyn S. R., D'Emden H. F., Kuehne G. 2012. Extensive use of no-tillage in grain growing regions of Australia. Field Crops Research, 132: 204-212. https://doi.org/10.1016/j.fcr.2012.03.013

23. Malidža G., Rajković M., Vrbničanin S., Božić D. 2015. Identification and distribution of ALS resistant Sorghum halepense populations in Serbia. Proceedings of $17^{\text {th }}$ ERWS Symposium. Montpellier, France, p. 115

24. Owen D. K. M. 2016. Herbicide-resistant weed management must include more than herbicides: proceedings of $7^{\text {th }}$ International Weed Science Congress. Prague, Czech Republic, p. 240.

25. Pannacci E., Graziani F., Covarelli G. 2007. Use of herbicide mixtures for pre- and post-emergence weed control in sunflower (Helianthus annuus). Crop Protection, 26: 11501157. https://doi.org/10.1016/j.cropro.2006.10.008

26. Peters B., Strek J.H. 2016. The global status of weed resistance and consequences for agricultural prctices. Proceedings of the $7^{\text {th }}$ International Weed Science Congress, Prague, Czech Republic, p. 76.

27. Popp J., Csider I. 2014. Competitive crop production: food-, energy- and environmental security. Proceedings of $13^{\text {th }}$ ESA Congress. Debrecen, Hungary, p. 11-16.

28. Simić M., Dolijanović Ž. 2016. Maize protection: the integrated weed management system benefits. Barnes L. (ed.). Zea mays L.: molecular genetics, potential environmental effects and impact on agricultural practices. New York, USA, p. 51-84.

29. Simić M., Brankov M., Dragičević V., Videnović Ž. Kresović B. 2012. Maize weed infestation under different soil tillage systems and fertilization levels. Herbologia (Sarajevo, Bosnia and Herzegovina), 13 (1): 59-72. http://www.anubih.ba/images/publikacije/herbologia/ herbologia_13_1.pdf

30. Simić M., Hamouzova K., Soukup J., Boz Ö., Dragičević V. 2013. Testing of annual weed species Solanum nigrum (L.) on resistance to triazine herbicides. Proceedings of $16^{\text {th }}$ European Weed Research Society symposium. Samsun, Turkey, p. 291 (poster presentation). http://www.ewrs.org/ doc/16th_EWRS_Symposium_Samsun_Turkey_2013.pdf

31. Simic M., Spasojevic I., Brankov M., Dragicevic V. 2014. Weeds seed bank richness in maize field: effects of crop rotation and herbicides. Proceedings of $5^{\text {th }}$ international scientific agricultural symposium Agrosym 2014. Jahorina, Bosnia and Herzegovina, p. 501-507. https://www. cabdirect.org/cabdirect/abstract/20153437535 
32. Simić M., Spasojević I., Kovacević D., Brankov M., Dragicević V. 2016. Crop rotation influence on annual and perennial weed control and maize productivity. Romanian Agricultural Research, 33: 125-133. http://www.incdafundulea.ro/rar.htm

33. Simić M., Dragičević V., Brankov M. 2017. Influence of growing measures to weed control and water use in maize. Herbologia (Sarajevo, Bosnia and Herzegovina), 16 (2): 35-48. https://doi.org/10.5644/Herb.16.2.03

34. Singh H. P., Batish D. R., Kohli R. K. 2003. Allelopathic interactions and allelochemicals: new possibilities for sustainable weed management. Critical Reviews in Plant Science, 22: 239-311. https://doi.org/10.1080/713610858

35. Spasojević I., Simić M., Dragičević V., Brankov M., Filipović M. 2012. Weed infestation in the maize stands influenced by the crop rotation and herbicide control. Herbologia (Sarajevo, Bosnia and Herzegovina), 13: 6978. http://www.anubih.ba/images/publikacije/herbologia/ herbologia_13_1.pdf

36. Spasojević I., Dragičević V., Simić M., Kovačević D., Brankov M. 2014. Effects of different cropping systems and weed management methods on free energy and content of pigments in maize. Pesticides and Phytomedicine (Belgrade, Serbia), 29 (1): 45-54 https://doi.org/10.2298/PIF1401045S

37. Swanton J. C., Weise F. S. 1991. Integrated weed management: the rationale and approach. Weed Technology, 5: $657-663$. https://doi.org/10.1017/S0890037X00027512

38. Swanton J. C., Nkoa R., Blackshow R. 2015. Experimental methods for crop-weed competition studies. Weed Science, 63 (spec. iss.): $2-11$ https://doi.org/10.1614/WS-D-13-00062.1

39. Travlos I., Economou G., Kanatas J. P. 2011. Corn and barnyardgrass competition as influenced by relative time of weed emergence and corn hybrid. Agronomy Journal, 103 1-6. https://doi.org/10.1017/S0021859611000876
40. Vasileiadis V., Otto S., van Dijk W., Urek G. 2015. On-farm evaluation of integrated weed management tools for maize production in three different agro-environments in Europe: agronomic efficacy, herbicide use reduction, and economic sustainability. European Journal of Agronomy, 63: 71-77. https://doi.org/10.1016/j.eja.2014.12.001

41. Videnović Ž., Simić M., Srdić J., Dumanović Z. 2011. Long term effects of different soil tillage systems on maize (Zea mays L.) yields. Plant, Soil and Environment, 57: 186-192. https://doi.org/10.17221/443/2010-PSE

42. Videnović Ž., Jovanović Ž., Dumanović Z., Simić M., Srdić J., Dragičević V., Spasojević I. 2013. Effect of long term crop rotation and fertilizer application on maize productivity. Turkish Journal of Field Crops, 18 (2): $233-$ 237. https://ec.europa.eu/eurostat/documents

43. Woźniak A., Kawecka-Radomska M. 2016. Crop management effect on chemical and biological properties of soil. International Journal of Plant Production, 10 (3): 391-401. https://doi.org/10.22069/IJPP.2016.2904

44. Weber J., Gerhards R. 2015. Influence of cover crops and tillage on weeds in soybean production in southern Germany. Proceedings of $17^{\text {th }}$ European Weed Research Society Symposium. Montpellier, France, p. 202. https:// www.cabi.org/ISC/FullTextPDF/2016/20163116696.pdf

45. Williams M. M., Boydston A. R., Davis S. A. 2008. Differential tolerance in sweet corn to wild-proso millet (Panicum miliaceum) interference. Weed Science, 56 (1): 91-96. https://doi.org/10.1614/WS-7-062.1

46. WRB. 2014. World reference base for soil resources. World Soil Resources Reports No. 106. FAO, p. 187-189.

47. Zhang J., Zheng L., Jäck O., Yan D., Zhang Z., Gerhards R., Ni H. 2013. Efficacy of four post-emergence herbicides applied at reduced doses on weeds in summer maize (Zea mays L.) fields in North China Plain. Crop Protection, 52: 26-32. https://doi.org/10.1016/j.cropro.2013.05.001

ISSN 1392-3196 / e-ISSN 2335-8947

Zemdirbyste-Agriculture, vol. 107, No. 1 (2020), p. 33-40

DOI $10.13080 /$ z-a.2020.107.005

\title{
Integruota piktžolių kontrolė kukurūzus auginant ilgą laiką
}

\author{
M. S. Simić1, V. Dragičević1 ${ }^{\text {, D. Chachalis }}{ }^{2}$, Ž. Dolijanović $^{3}$, M. Brankov ${ }^{1}$ \\ ${ }^{1}$ Kukurūzų tyrimų institutas Zemun Polje, Serbija \\ ${ }^{2}$ Benaki fitopatologijos institutas, Graikija \\ ${ }^{3}$ Belgrado universiteto Žemès ūkio fakultetas, Serbija
}

\section{Santrauka}

Straipsnyje analizuojama kukurūzų ịvairių auginimo priemonių ir auginimo technologijų įtaka piktžolių mažèjimui ilgalaikio eksperimento metu.

Europoje tvaraus kukurūzų auginimo svarbiausias prioritetas yra integruota piktžolių kontrolès (IPK) sistema, kuria siekiama sumažinti priklausomuma nuo cheminès piktžoliu kontrolès. IPK sistema apima visus ìmanomus sprendimus, pavyzdžiui, prevencines tiesiogines, biologines, mechanines ir alternatyvias priemones. Augalininkystės sistemų metodas yra labai svarbus siekiant kontroliuoti piktžoles, išnaudoti kukurūzų genotipų genetinį potencialą ir sumažinti derliaus nuostolius dèl piktžolių.

Siais laikais ilgalaikiai eksperimentai vykdomi retai, tačiau jie yra puikus ir patikimas būdas augalininkystès sistemas palyginti pagal derlių ir pasėlių piktžolètumo mažinimą. Centrineje Serbijoje esančiame Kukurūzu tyrimu institute Zemun Polje igyvendinant mokslinių tyrimų programą, kelerius metus kaip IPK dalis buvo tirta įvairių agrotechnikos priemonių itaka ir jų sąveika. Siekiant sumažinti piktžolių biomasę efektyviausia buvo paprastujų kukurūzų (Zea mays L.) sėjomaina su žieminiais kviečiais ir sojomis kartu su herbicidų panaudojimu - atitinkamai 92,1 ir $92,2 \%$. Žieminiai kviečiai buvo geresnis kukurūzu priešsèlis nei sojos, ypač kartu su herbicidais, panaudojus ir rekomenduojamą normą, ir pusę rekomenduojamos jų normos. Žemès dirbimas turejjo reikšmingos įtakos kukurūzu pasėlio piktžolètumui, ypač daugiametėms piktžolèms: Sorghum halepense (L.) Pers., Cirsium arvense (L.) Scop. ir Convolvulus arvensis L. Kitos priemonès, pavyzdžiui, trąšų rūšis, kukurūzų tarpueilių plotis ir augalų tankumas, antsèlis bei isèlis, taip pat turèjo itakos piktžolių biomasei kukurūzu lauke. Kukurūzu auginimas mažesniu tarpueilių pločiu piktžolių biomasę sumažino $27,4 \%$, o lètai atpalaiduojamo karbamido panaudojimas padidino augalų konkurencinę gebą. Saldžiujų kukurūzų (Zea mays L. convar. saccharata), augintų su vikių antsėliu, pasėlyje piktžolių biomasė reikšmingai sumažèjo $\left(48,5 \mathrm{~g} \mathrm{~m}^{-2}\right)$, palyginus su variantu be antsėlio $\left(564,3 \mathrm{~g} \mathrm{~m}^{-2}\right)$.

Reikšminiai žodžiai: cheminè kontrolè, integruota piktžolių kontrolè, kukurūzai, priemonių sistema, Zea mays. 